\title{
UMA CRÍTICA HERMENÊUTICA AO PSEUDO PRINCÍPIO DA AFETIVIDADE
}

\author{
A HERMENETIC CRITICAL TO THE PSEUDO PRINCIPLE OF AFFECTIVENESS
}

\begin{abstract}
Simone Alvarez Lima
Doutora pela Universidade Estácio de Sá, na linha de pesquisa Direitos Fundamentais e Novos Direitos. Especialista em Direito Civil e Internacional. E-mail: sissyalvarez22@yahoo.com.br
\end{abstract}

Recebido em: 11/06/2018

Aprovado em: 15/04/2019

\begin{abstract}
RESUMO: O pseudo princípio da afetividade é uma construção da jurisprudência no Brasil que vem ganhando força ao longo dos anos, mesmo sem estar expressamente previsto em nenhuma lei. Streck é um autor que o entende como um pseudo princípio e alerta a algum tempo sobre os riscos do uso, dentre eles a discricionariedade judicial. A aplicação do princípio da afetividade foi feito de forma voluntária pelos juízes, demonstrando o descompromisso com a deontologia do direito e isto resultou na permissão judicial para situações que a lei não permite, tais como conceder direitos à concubina, dois pais e uma mãe ou vice-versa registrando um filho e na união estável poliafetiva.
\end{abstract}

Palavras-chave: Hermenêutica.Princípio da afetividade.Normatividade.Discricionariedade.

ABSTRACT: The pseudo principle of affectivity is a construction of jurisprudence in Brazil that has been gaining strength over the years, even though it is not expressly provided for in any law. Streck is an author who understands it as a pseudo principle and warns at some time about the risks of use, among them judicial discretion. The application of the principle of affectivity was done voluntarily by the judges, demonstrating the disagreement with the deontology of the law and this resulted in the judicial permission for situations that the law does not allow, such as granting rights to the concubine, two parents and a mother or vice -versa registering a child and in the stable union poliafetiva.

Keywords: Hermeneutics.Affectivity principle.Normativity.Discretionarity.

SUMÁRIO: Introdução. 1- Da dignidade humana ao princípio da afetividade. 2- Uma crítica à discricionariedade do juiz. 3- Jurisprudência substituindo o legislador. Conclusão. Referências.

\section{INTRODUÇÃO}

O artigo a seguir se destina a uma crítica hermenêutica a um princípio (na verdade, pseudo princípio) que vem sendo utilizado cada vez mais sem critério: o pseudo princípio da 
afetividade, normalmente entendido pelos juristas como derivado do princípio da dignidade da pessoa humana, insculpido no art. $1^{\circ}$, III da Constituição Federal vigente.

A relevância desta pesquisa reside no fato de que alguns juízes, após o neoconstitucionalismo, têm adotado uma postura solipcista ao criar direitos e princípios que não existem, expressamente,na legislação, sob o manto do princípio da dignidade humana. A partir deste princípio, queé despido de conteúdo jurídico e mais relacionado à moral, muitas decisões são justificadas, acarretandono decisionismo, na discricionariedade eno ativismo judicial, fazendo com que os aplicadores do direito se assenhorem da Constituição Federal, chegando ao ponto de se substituíremao legislador.

Um dos ramos em que o pseudo princípio da afetividade é muito mencionado é o Direito de Família, no qual "surgiram" direitos que o legislador não previu mas criados pelo voluntarismo jurisprudencial, tais como: a permissão de registro de dois pais e uma mãe ou uma mãe e dos pais na certidão de nascimento de uma criança (sendo que o previsto pelo legislador é que a adoção extingue o poder familiar biológico); divisão de pensão de esposa com amante concubina (sendo que o legislador previu que o concubinato não gera obrigações); união estável poliafetiva (sendo que o legislador previu a união estável entre um homem e uma mulher ou, no máximo, de duas pessoas de mesmo sexo, a partir da Resolução $n^{\circ} 175$ do Conselho Nacional de Justiça).

Como nem o Código Civil e nem a Constituição Federal citaram a palavra afeto ${ }^{1}$, todas essas situações demonstram o decisionismo judicial e o mais preocupante é que o STJ e o STF estão decidindo questões com base na afetividade, conforme dados da pesquisa realizada em 04 de dezembro de 2016.

O primeiro item do presente artigo esclarece ao leitor o princípio da afetividade, já que ele é o foco da crítica hermenêutica; o segundo aborda a discricionariedade judicial e o terceiro item se destina a mostrar casos em que há discricionismo judicial e a aplicação do princípio da afetividade, criando situações jurídicas não previstas, ou melhor, contrárias ao previsto na lei. Assim, nesses dois últimos itens reside a crítica hermenêutica ao princípio da afetividade.

Para a elaboração desta pesquisa foram utilizadas doutrinas e artigos que explicam o pseudo princípio da afetividade, o levantamento de dados nos sites do STF e STJ aonde foi feita pesquisa sobre a utilização dos termos princípio da afetividade e afetividade, obras de LenioStreck, o qual foi o marco teórico da abordagem, tendo em vista ser um dos poucos juristas a perceber o perigo do uso indiscriminado deste pseudo princípio, usado pelo aplicador do direito como substituinte de situações legalmente previstas. Além deste, foram usadas outras obras de hermenêutica jurídica que criticam o ativismo judicial. Trata-se de uma pesquisa quantitativa uma vez que analisará os dados apresentados sem enfocar dados quantitativos (esses apenas aparecem quando da informação da quantidade de decisões do STJ e STF).

\section{DA DIGNIDADE HUMANA AO PRINCÍPIO DA AFETIVIDADE}

Após o neoconstitucionalismo, os valores constitucionais de liberdade, igualdade, dignidade e solidariedade incidiram no Direito de Família, permitindo a releitura de diversas categorias jurídicas, muitas delas mais aptas às demandas da plural sociedade do presente. A aproximação com a experiência concreta e a evolução social e tecnológica fez o Direito brasileiro perceber a relevância que era socialmente conferida à afetividade, mesmo com o paralelo avanço de técnicas científicas que favoreciam a descoberta dos vínculos biológicos. "Houve um movimento crescente na defesa do reconhecimento da ligação afetiva como suficiente nas

\footnotetext{
${ }^{1}$ A palavra "afetividade" apenas foi mencionada na Lei $\mathrm{n}^{\circ}$ 12.210, de 03 de agosto de 2009, que dispõe sobre adoção.
} 
relações familiares, já que apenas os elos matrimoniais, biológicos e registrais não davam conta das variadas situações que se apresentaram”. (CALDERÓN, s/d).

Opseudo princípio da afetividade é citado, frequentemente, no Direito de Família. Segue, a título de exemplo, a importância da afetividade para Dias, in fine:

A família transforma-se na medida em que se acentuam as relações de sentimentos entre seus membros: valorizam-se as funções afetivas da família. Despontam novos modelos de família, mais igualitárias nas relações de sexo e idade, mais flexíveis em suas temporalidades e em seus componentes, menos sujeitas à regra e mais ao desejo. (DIAS, 2006, p. 60).

Não apenas no Direito deFamília, mas em todo o ordenamento jurídico, o princípio insculpido na Constituição Federal, em seu art. $1^{\circ}$, III, dignidade da pessoa humana, tem relevância, sendo citado em, praticamente, todas as petições iniciais como a pedra angular valorativa da Constituição Federal de 1988. Barreto (2013, p. 63) alerta que a utilização do princípio da dignidade da pessoa humana não tem sido acompanhada de uma reflexão a respeito de seus fundamento ético-filosóficos e que "essa falta de reflexão crítica sobre tema de tamanha importância na cultura jurídica brasileira tem tido como consequência o emprego indiscriminado do princípio para tudo abranger e justificar."

Com a falta de reflexão crítica, o emprego indiscriminado da dignidade humana tem resultado no pamprincipiologismo e na flambagem do direito, palavras usadas por Streck(2013), que exemplifica alguns princípios que os juízes "criam" com base na dignidade humana, quais sejam, princípio da humanidade, princípio da não surpresa, inclusive, o princípio da afetividade. Ressalta-se, desde já, que nem a Constituição Federal e nem o Código Civil mencionam a palavra afeto ou afetividade, sendo o princípio citado como incluído no princípio da dignidade da pessoa humana.

Streck(2014) levanta a crítica do fato de tornar princípio tudo aquilo que deriva da dignidade, indagando: "por que razão não elevar ao status de princípio o amor, o companheirismo, a paz, a proibição da tristeza, enfim, tudo o que pode ser derivado do respeito do princípio da dignidade da pessoa humana, alçado à categoria de "superprincípio"? Por que só a afetividade?" Ora, tendo em vista que um valor humano foi elevado à categoria de princípio, isso significa que outros valores ficaram preteridos.

Barreto (2013, p. 63) explica que o fetiche pelos direitos humanos ocorre, justamente, devido ao uso indiscriminado do princípio da dignidade humana, o qual fornece alicerce para a aplicação para o pseudo princípio da afetividade:

O fascínio pela expressão direitos humanos serve muitas vezes como guardachuva ideológico, legitimador de teorias e práticas a mais diversas. Essa pouca elaboração teórica tem a ver com o fato de que a palavra não é um conceito propriamente jurídico. (BARRETO, 2013, p. 63).

A dignidade humana como alicerce para a aplicação do princípio da dignidade é comprovada a partir dos dizeres da ementa da decisão proferida na apelação do processo $\mathrm{n}^{\circ}$ 0012691-17.2010.8.19.0026, segundo a qual "identifica-se no Brasil de hoje a plena observância ao princípio da afetividade como uma espécie do princípio geral da dignidade da pessoa humana, que privilegia os laços sociais e afetivos." O Relator desta decisão foi o Desembargador Juarez Fernandes Folhes do Tribunal de Justiça do Rio de Janeiro.

Este princípio vem sendo aplicado quando a lei e/ou a Constituição prevê algo diferente do que o aplicador do Direito pensa. O julgador chega ao ponto de criar princípios não-legais. Streck(2013), em seu artigo intitulado O pamprincipiologismo e a flambagem do Direito, aponta alguns princípios que são apenas uma "carta na manga do juiz", mas que não ostentam 
normatividade e, dentre eles, cita o princípio da afetividade, o qual critica por levar "a compreensão do direito como subsidiário a juízos morais, sendo um álibi para justificar decisões pragmatistas." Essas decisões pragmatistas se relacionam com o fato de que a hermenêutica brasileira não é algo estático.

Morais e Fausto (2015, p. 111) se perguntam se o dirigismo constitucional merece permanecer na teoria constitucional brasileira e concluem que "a fenomenologia hermenêutica implica na exigência de se repensar os fenômenos ao longo do tempo, procurando, a cada momento, estabelecer uma visão mais crítica e reflexiva sobre as coisas." Em outras palavras, isso significa que a hermenêutica brasileira deve considerar que os direitos fundamentais devem ser vistos como uma orientação para a sociedade que vive sob uma Constituição compromissória.

Em pesquisa realizada no site do Tribunal de Justiça do Estado do Rio de Janeiro, foi verificado que há decisões que citam a expressão "princípio da afetividade", segue outra delas:

Apelação cível. Ação negatória de paternidade cumulada com pedido de anulação de registro. Pedido julgado improcedente. Paternidade socioafetiva demonstrada. Prevalência sobre a paternidade de cunho biológico. Provimento NEGADO. 1. Hodiernamente, a filiação pode decorrer de vínculo biológico, legal ou afetivo. (...) A terceira vertente constitui verdadeira renovação do instituto, trazida por evolução constitucional, ligada ao princípio da afetividade. (TJRJ, processo $\mathrm{n}^{\circ}$ 0071984-13.2009.8.19.0038 - Desembargador Gilberto Clóvis Farias Matos)

Este pseudo princípio não é aplicado apenas na $1^{\mathrm{a}}$ Instância, pois os Tribunais Superiores também consideram a afetividade em suas decisões. Em pesquisa ao site do Superior Tribunal de Justiça, em 04 de dezembro de 2016, foi verificado que há 19 acórdãos que citam a "afetividade"2 Já no site do Supremo Tribunal Federal, a pesquisa encontrou 17 documentos que citam a afetividade, sendo 1 acórdão, 13 decisões monocráticas e 3 informativos ${ }^{3}$. Dentre esses informativos, vale mencionar os dizeres do informativo $n^{\circ} 626$, que dispõe:

Com efeito, a partir do momento em que a Constituição Federal reconheceu o amor como o principal elemento formador da entidade familiar nãomatrimonializada, alçou a afetividade amorosa à condição de princípio constitucional implícito, que pode ser extraído em função do art. $5 .^{\circ}, \$ 2 .^{\circ}$, da $\mathrm{CF} / 1988$, que permite o reconhecimento de princípios implícitos por decorrentes dos demais princípios e do sistema constitucional (além dos tratados internacionais de direitos humanos dos quais o Brasil faça parte). (STF, informativo 626).

Este informativo cita o art. $5^{\circ}, \S 2^{\circ}$ que estabelece que "os direitos e garantias expressos nesta Constituição não excluem outros decorrentes do regime e dos princípios por ela adotados, ou dos tratados internacionais em que a República Federativa do Brasil seja parte" para justificar o uso do princípio da afetividade, porém, não existe tratado internacional que cite este pseudo princípio. Como afirma Silva (2016), o princípio da afetividade não merece ser tratado com tamanha primazia, pois não concorda que relações unicamente fundadas em afeto prevaleçam "sobre as que se fundam na incidência das normas jurídicas positivadas, aprovadas pelo

\footnotetext{
${ }^{2}$ Decisões do STJ: AgRg no AREsp 71290; REsp 1330404; REsp 1328380; REsp 1449560; REsp 1348458; REsp 1115428; HC 181246; REsp 1328306; REsp 922462; REsp 1347228; REsp 1159242; REsp 866220; REsp 1000356; REsp 1157273; REsp 1107192; REsp 1172067; REsp 945283; HC 128229; REsp 526299.

${ }^{3}$ STF: Acórdãos: RHC 104261; Decisões monocráticas: ARE 1010628/MG; Rcl 23650 MC/DF; ARE 957035/SP; Rcl 14475/RJ; RE 613373/RJ; ARE 779543/RJ; HC 114901 MC/CE; RE 615941/RJ; AI 746096/MG; RE 643229/RS; AI 847778/RJ; AI 843707/RJ; AI 588373/SE; Informativo: HC -114901- Informativo 690; HC104907- Informativo 626; ADPF -132-Informativo 625.
} 
Parlamento, cujo conhecimento é inescusável, com efeitos erga omnes." Complementando os dizeres do autor, para Streck(2008, p. 141), não se deve admitir que os tribunais se assenhorem da Constituição Federal, pois o intérprete, em nome da interpretação do texto, "não pode dizer qualquer coisa sobre qualquer coisa."

Sobre a falta de normatividade internacional do pseudo princípio da afetividade Silva menciona:

O grande erro do principiologismo que se criou em torno da afetividade é um absurdo sem precedentes na ordem jurídica interna, na ordem internacional e nas ordens jurídicas estrangeiras. Não há em nenhum outro sistema jurídico internacional qualquer coisa semelhante. Tão pouco na ordem dos tratados internacionais há qualquer menção a direitos e relações jurídicas (e deveres e obrigações) oriundas de relações socioafetivas. (SILVA, 2016)

Assim, verifica-se que a expansão do uso do princípio da afetividade é devido à uma interpretação extensiva do princípio da dignidade humana. O próprio termo princípio da afetividade é fruto da decisão do sujeito solipcista, que leva à necessidade de uma crítica hermenêutica. Deste modo, passar-se-á para o próximo item no qual serão analisados a discricionariedade e o decisionismo judicial quando o magistrado utiliza a pamprincipiologia e pseudo princípios ao julgar decisões com conteúdo moral.

\section{UMA CRÍTICA À DISCRICIONARIEDADE DO JUIZ}

Streck(2014) alerta sobre os riscos dopamprincipiologismo, que é a criação de princípios que são utilizados contra a lei ordinária e contra à Constituição Federal em nome de valores morais. Dentre os pseudo princípios está o princípio da afetividade, que costuma ser usado por juízes pragmatistas e de forma antidemocrática. Em seu livro da série $O$ que é isto - decido conforme minha consciência - Streck(2015, p. 51) julga incompatível com a democracia uma Constituição que“estabelecesse princípios que autorizassem o juiz a buscar em outros espaços ou fora dele, as fontes para complementar a lei." 4

Mas por qual motivo esses pseudo princípios ingressaram no ordenamento jurídico com tanta força, a ponto de ser tão citado na jurisprudência, inclusive, levando juízes a decidirem contra legem? Pois bem, a discussão a respeito do positivismo e sua insuficiência na proteção das pessoas frente ao autoritarismo do Estado já vem de muito tempo. ${ }^{5}$

No século XIX, o direito natural foi empurrado para a margem da história por ser considerado metafísico, o que não se pode negar, afinal, ele remonta à compreensão de normas superiores ao racionalismo humano eéanti-científico.Já o positivismo ficou em seu apogeu, dominando o pensamento jurídico, até meados do século XX (BARROSO, 2015). O direito natural, com seu conteúdo moral, não trazia para a sociedade a segurança jurídica necessária.

O Direito positivo é, conforme definição de Bobbio (1995, p. 19), aquele que foi "posto pelo poder soberano do Estado, mediante normas gerais e abstratas, isto é, como lei." $\mathrm{O}$ positivismo jurídico se realiza quando a lei se torna a fonte explicita, ou, de qualquer modo,

\footnotetext{
${ }^{4}$ Um artigo deste gênero se encontra na Lei de Introdução ao Direito Brasileiro, qual seja, o art. $4^{\circ}$, que dispõe que "quando a lei for omissa, o juiz decidirá o caso de acordo com a analogia, os costumes e os princípios gerais de direito."

${ }^{5}$ Conforme BARROSO (2015) leciona, “a decadência deste no século XX, na Europa, é associada à derrota do fascismo na Itália e do nazismo na Alemanha, regimes que promoveram a barbárie sob a proteção da legalidade. Ao fím da $2^{a}$ Guerra, os valores começam a retornar ao Direito."
}

Revista de Direito Brasileira | Florianópolis, SC | v. 23 | n. 9 | p.197-210 |Mai./Ago. 2019 
prevalente, do Direito, sendo usado com maior frequência, fundamentando decisões. ${ }^{6}$ Em contrapartida, um autor que sugeria corrigir o direito através da moral é Radbruch, cuja fórmula ficou conhecida no mundo jurídico:

quando as leis conscientemente desmentem o desejo de justiça, como quando arbitrariamente concedem ou negam a certos homens os direitos naturais da pessoa humana, carecerão de qualquer validade, o povo não lhes deverá obediência, e os juristas deverão ser os primeiros a recusar-lhes o caráter de jurídicas. (RADBRUCH, 1974, p.415)

A fórmula de Radbruch não teve muita repercussão devido a possibilidade de rompimento institucional com a insegurança jurídica que poderia provocar (STRECK, 2016, p. 53). Bustamante (2012, p. 154) explica que se esta fórmula pudesse ser filosoficamente reconhecida, então que fosse acompanhada por algum critério que permitisse ao jurista dar objetividade à sua aplicação, "pois sem isso, ela não se acomoda bem com a teoria da argumentação jurídica e à concepção de racionalidade."

A discricionariedade judicial agradaa autores adeptos da teoria da argumentação, que entendem que determinados princípios aumentam a margem de interpretação para o aplicador do Direito, mas, na realidade, o círculo para a discricionariedade se fecha. Streck(2008, p. 171) ressalta que, na realidade, a importância dos princípios está em impedir "múltiplas respostas" para um mesmo caso. Para o autor, princípios não são cláusulas abertas a serem preenchidas pela livre atuação da subjetividade do juiz. Isso é abrir as portas para o solipsismo, e exemplo disso são expressões como "princípio da afetividade"; "poliafetivos", as quais não foram construções legislativas. O solipsismo leva o juiz a "colmatar lacunas ou incompletudes legislativas a partir da "descoberta" de valores que estariam em uma metajuridicidade".

Um autor que defende a discricionariedade judicial é Tavares (2007), segundo o qual "quando não houver regras que possam solucionar uma lide, os juízes detêm um poder discricionário para criar a norma individual que regulará o caso concreto." Contudo, na compreensão de Streck(2015, p. 51), a Constituição Federal não permite emendas por qualquer aplicador do Direito à revelia do processo legislativo regulamentar sob pena de incorrer em ativismo judicial, que desaguariam em decisionismos como os que ocorreram nas decisões a serem estudadas no item a seguir. Essa discricionariedade, cuja característica é a utilização da moral própria do juiz na hora de julgar, é antidemocrática, pois o juiz discricionário analisa a norma "matando o personagem principal"" Kelsen já alertava para a necessidade de separação entre a teoria do Direito e a moral, pois caso não houvesse essa separação, seria necessário pressupor uma moral absoluta e não apenas a de um juiz, o que não existe. Há, isso sim, diversos sistemas de moral.

Quando uma ordem jurídica é valorada como moral ou imoral, isso traduz a relação entre a ordem jurídica e um dos vários sistemas de moral, e não a relação entre aquela e "a" moral. É enunciado um juízo de valor relativo e não absoluto.

\footnotetext{
${ }^{6}$ Streckem seus livros explica que o mal do positivismo é que ele acaba gerando múltiplas respostas para um determinado problema, e isso entra em choque com o fato de que o cidadão tem direito a uma decisão hermeneuticamente correta. "A crítica hermenêutica do Direito é uma nova teoria que exsurge da fusão dos horizontes da filosofia hermenêutica, da hermenêutica filosófica e da teoria integrativa dworkiana. Dela exsurge a tese de que há um direito fundamental a uma resposta correta, entendida como "adequada à Constituição." (STRECK, 2015, p. 97).

${ }^{7}$ A morte do personagem principal da norma é uma analogia utilizada por Streck(2015, p. 99) ao explicar o Direito como integridade de Dworkin, segundo o qual "por mais que o julgador desgoste de determinada solução legislativa e da interpretação possível que dela se faça, não pode ele quebrar a integridade do direito, estabelecendo um "grau zero de sentido", como que, fosse o direito uma novela, matar o personagem principal, como se isso - a morte do personagem- não fosse condição para a construção do capítulo seguinte."
} 
Isso significa que a validade de uma ordem jurídica positiva é independente da sua concordância ou discordância com qualquer sistema de moral. (KELSEN, 2008, p. 77).

Nesse diapasão, Streck(2015, p. 59) ensina que é tarefa da teoria do direito diminuir, se possível, eliminar os espaços de discricionariedade judicial porque quanto menos subjetivismo, mais democracia. Não é tarefa do Poder Judiciário legislar ordinariamente sob pena do juiz se tornarsolipcista. Os ensinamentos de Waldron(2010, p. 140) confirmam que não é tarefa do juiz legislar, mesmo sendo o sistema de eleições legislativa imperfeito, ele é "superior por ser questão de democracia e de valores democráticos em comparação à base indireta e limitada de legitimidade democrática do judiciário." Para este autor, os legisladores podem ser responsabilizados por seus atos perante seus eleitores na tomada de uma decisão política, o que não acontece com os integrantes do Poder Judiciário. Além disso, os Legisladores são substituídos depois de quatro anos, mas um juiz nunca é substituído.

A discricionariedade judicial também tem como característica a busca de correção ao Direito, mas, conforme leciona Bustamante (2012, p. 150), essa pretensão corretiva "atribui ao Direito um caráter ideal que desautoriza todos os positivismos que definem o ordenamento jurídico como mera facticidade ou expressão de poder ou autoridade." O autor trabalha a hipótese de que o objetivo de correção do direito pela moral poderia fazer com que o aplicador do Direito se utilizasse de um princípio geral de moralidade, válido para todos os ramos jurídicos, independentemente de qualquer normatividade. Não é necessário pensar muito para verificar que este tipo de situação não traz segurança jurídica.

Dworkin(2010, p.03), na introdução do seu livro Justiça de Toga, indaga ao leitor: "como as convicções morais de um juiz devem influenciar seus julgamentos acerca do que é direito?"Ele responde que as respostas variam, indo de "nada" a "tudo", e nesta variação de respostas a respeito das convicções morais dos juízes é que o Brasil, atualmente, enfrenta uma onda de pamprincipiologismo.

Acreditar que uma decisão judicial é produto de um ato de vontade do juiz leva a um fatalismo em que "tudo dependeria da vontade pessoal (se o juiz quer fazer, faz se não quer, não faz). Logo, a própria democracia não dependeria de nada para além do que alguém quer." (STRECK, 2015, p. 43).

Para finalizar este item referente à crítica à discricionariedade judicial, vale mencionar o que Streck(2008, p. 216) escreveu em seu livro Verdade e Consenso: “o direito não é aquilo que o intérprete quer que ele seja. Portanto, o direito não é aquilo que o Tribunal, no seu conjunto ou na individualidade de seus componentes,diz que é." Combate-se não a interpretação, mas a aplicação de sentido arbitrário aos textos legais, como se texto e norma fossem itens diferentes e separados, o que foi verificado nos casos a seguir explicados em que foram aplicado o princípio da afetividade para justificar a aplicação da norma com sentido diferente do previsto pelo legislador.

\section{JURISPRUDÊNCIA QUE SE SUBSTITUI AO LEGISLADOR}

Aqueles que defendem a discricionariedade judicial e a interpretação ampla da lei o fazem para proteger as minorias contra a tirania da maioria, tendo em vista que o parlamento e/ou congresso são formados de forma majoritária. Waldron(2010, p. 145) explica que ainda que a decisão de uma maioria seja tirana, essa tirania existirá em qualquer discordância a respeito de direitos. A decisão oriunda de uma maioria popular não tem como ser tirânica, uma vez que "a decisão não foi tomada de uma maneira que excluísse tiranicamente determinadas pessoas da participação como iguais". 
Waldron(2010, p. 148) entende que não é tirania quando a lei não protege determinado direito que a minoria gostaria que protegesse: "pessoas, incluindo membros de minorias tópicas, não têm necessariamente os direitos que pensam ter. Elas podem estar erradas quanto aos direitos que têm." $\mathrm{Na}$ época em que os pedidos analisados neste item foram julgados, não havia possibilidade jurídica para proteger as pretensões como colocar três pais em certidão de nascimento, divisão de pensão com concubina e nem união estável poliafetiva.

O maior campo de aplicação do pseudo princípio da afetividade é o Direito de Família, pois é a família o âmbito em que mais há relações humanas mais próximas, que vão do amor ao ódio. Soma-se a isto o fato de que a Constituição Federal de 1988 trouxe diversas inovações, dentre elas a igualdade entre homem e mulher $\left(\operatorname{art} .5^{\circ}, \mathrm{I}\right)$, a união estável entre homem e mulher (art. 226, $\S 3^{\circ}$ ), a entidade familiar formada por qualquer dos pais e seus descendentes (art. 226, $\S 4^{\circ}$ ) e o Código Civil de 2002 foi promulgado sob o enfoque desta Constituição Cidadã.

Em julgamentoscomo os descritos neste item, a utilização do pseudo princípio da afetividade substituiu a vontade do legislador. Em setembro de 2014, quando Streckpublicou o artigo Por analogia, advogados devem invocar em seu favor o princípio da amorosidade, parecia que estava prevendo o que iria acontecer alguns anos mais tarde. Eis suas palavras:

Em nome da "afetividade", tudo é possível, como registrar dois ou três pais para um filho (duas mães e um pai - leia aqui) registrar filho só com pais (sem mãe), dar a metade da herança para a amante-concubina-adulterina, etc (rogo para que os comentaristas não se digladiem sobre se um filho pode ser registrado com dois pais e sem mãe. (STRECK, 2014)

Apesar de não ser contra a aplicação do princípio, Tartuce(2012) reconhece que o princípio da afetividade não está explícito no ordenamento jurídico brasileiro, pois afirma que "apesar da falta de sua previsão expressa na legislação, percebe-se que a sensibilidade dos juristas é capaz de demonstrar que a afetividade é um princípio do nosso sistema."

Vale mencionar, a fim de garantir uma leitura crítica dos casos a seguir, que Waldron(2010, p. 153) entende que a intervenção do Poder Judiciário, ao invadir a competência do Poder Legislativo, tal como ocorre nos casos mencionados, retarda uma reforma política. Ele comenta que a pessoa que sofre com determinada situação pode pensar, com pressa na solução do caso concreto, que: "algumas questões de direitos são urgentes demais para aguardar o surgimento de um legislativo mais responsável e representativo.” Waldron(2010, p. 154) rechaça esse argumento ao entender que isto torna ainda mais difícil reformar o legislativo, o qual passará a levar o direito menos a sério, pois saberão que os tribunais estarão disponíveis para auxiliá-lo e, assim, será "mais difícil desenvolver uma cultura mais responsável entre os legisladores."

A partir das interpretações feitas por autores que são contra a discricionariedade e o decisionismo, como Strecke Waldron,e das demais considerações acima, seguem alguns casos julgados no Brasil que comprovam o pamprincipiologismo e o decisionismo que alguns juízes manifestam em suas decisões, fundamentadas no pseudo princípio da afetividade, indo além da adequada/necessária intervenção jurisdicional.

a) Dois pais e uma mãe ou duas mães e um pai

Na vida prática, não é incomum uma criança dizer que possui dois pais, um do coração e um biológico (ou duas mães). Não há nada de errado nisto, pois apesar do afeto não estar escrito na lei, não é possível negar a sua existência no sentido sociológico. Por outro lado, não a lei em si, mas o Poder Judiciário está querendo conceder a este sentimento um conteúdo normativo inexistente. Uma reportagem da revista Exame abordou o tema multiparentalidade, narrando que decisões judiciais têm aberto caminho para que, em um registro civil, coexistam, sem conflitos, dois pais e uma mãe ou um pai e duas mães. 
A ideia defendida por alguns juízes, promotores e advogados é de que disputas entre quem "cria" e a mãe ou o pai biológico da criança podem virar "filiação tripla" no registro civil. A ideia defendida por alguns juízes, promotores e advogados é de que disputas entre quem "cria" e a mãe ou o pai biológico da criança podem virar "filiação tripla" no registro civil (BOTTINI FILHO, 2013).

A primeira dupla maternidade no Brasil surgiu em Goiânia, quando a juíza Sirlei Martins da Costa, da $1^{\mathrm{a}}$ Vara de Família e Sucessões, reconheceu a relação multiparental de um casal de duas mulheres e de um amigo em comum, pai biológico, de uma menina chamada Isadora. A juíza deu tamanha prioridade ao vínculo afetivo que, após examinar algumas provas, como depoimentos de familiares, diário da gravidez e declarações da escola onde a menina estuda, que julgou a ação sem a necessidade de ver as duas mães e o pai biológico pessoalmente, sem precisar de audiência. A juíza ainda citou que "a relação socioafetiva é fato que não pode ser, e não é, desconhecido pelo Direito" e para embasar seus dizeres, trouxe à tona jurisprudência do STJ (TJGO, 2015), mas nem sequer citou o artigo em que a socioafetividade está expressa enão o fez porque não existe. ${ }^{8}$

Em São Paulo, no ano de 2015, surgiu a primeira certidão de nascimento brasileira ${ }^{9}$ em que uma criança de dois anos foi registrada com dupla paternidade, após uma decisão do Foro Regional de Itaquera, da Juíza Felícia Jacob Valente, da $3^{\text {a }}$ Vara de Família e Sucessões, que permitiu o nome do pai biológico junto com o nome do pai socioafetivo na certidão de nascimento. (G1, 2015)

Este caso da dupla paternidade viola o art. 41 do Estatuto da Criança e do Adolescente, que dispõe que "a adoção atribui a condição de filho ao adotado, com os mesmos direitos e deveres, inclusive sucessórios, desligando-o de qualquer vínculo com pais e parentes, salvo os impedimentos matrimoniais." Logo, é juridicamente impossível haver mais de dois pais na certidão de nascimento de alguém, sendo um biológico e o outro adotivo.

A este respeito, vale trazer a ponderação de Silva (2016), segundo o qual "ainda que as pessoas civis sejam (e em verdade são) livres para manterem a relação socioafetiva que quiserem, não é possível aceitar a atribuição de efeitos jurídicos a toda e qualquer relação interpessoal puramente por existir um afeto.”

Como este artigo não é destinado a ser contra as relações de afeto serem reconhecidas pela lei, mas sim, contra o decisionismo judicial, que tem dado primazia à relações oriundas do afeto, com fundamento no pseudo princípio da afetividade, parabeniza-se o legislador que, através da Lei $n^{\circ} 11.924 / 2009$, incluiu o $\$ 8^{\circ}$ ao art. 57 da Lei $n^{\circ} 6.015 / 1973$, que trata sobre os registros públicos. Devido a este parágrafo, o enteado (a) poderá requerer ao juiz competente "que, no registro de nascimento, seja averbado o nome de família de seu padrasto ou de sua madrasta, desde que haja expressa concordância destes, sem prejuízo de seus apelidos de família." Ou seja, neste caso, em que há evidente decisão da pessoa devido ao afeto que sente por seu padrasto ou madrasta, caso o juiz acolha o pedido, não estará incorrendo em decisionismo, uma vez que está aplicando uma lei elaborada pelo Poder Legislativo, logo,não estará criando um direito que não existe.

\footnotetext{
${ }^{8}$ Palavras da Juíza: Verifico que a criança é cercada de todos os cuidados necessários ao seu desenvolvimento. O ambiente familiar é saudável, envolto de amor, carinho, afeto, respeito e felicidade. Está comprovado nos autos que a criança sente o mesmo amor, carinho, afeto, confiança e segurança por todos os seus genitores - biológicos e socioafetivo - motivo pelo qual em respeito ao princípio da dignidade humana e aos novos desdobramentos a que o conceito de entidade familiar tem passado, entendo por bem deferir o pedido inicial. (TJGO, 2015)

${ }^{9}$ No mundo, a primeira certidão com múltipla paternidade foi na Argentina, em 2013. Os progenitores justificaram seu pedido ao Governo de Buenos Aires pela necessidade de "assegurar a Antonio seu direito à identidade integral e seu direito de ser reconhecido como filho de suas duas mães e de seu pai, sem que tenha que renunciar a nenhum de seus direitos e obrigações". (REBOSSIO, 2015)
} 


\section{b) Pensão para a amante concubina}

Não houve emenda à lei, mas sim uma decisão judicial contrária a lei. Em junho de 2015, uma decisão da Turma Regional de Uniformização dos Juizados Especiais Federais da $4^{\mathrm{a}}$ Região concedeu a uma amante o direito de dividir a pensão por morte com a esposa de um homem. O pedido havia sido negado pela $2^{\text {a }}$ Turma Recursal do Rio Grande do Sul, mas a autora recorreu e pediu a uniformização de jurisprudência com prevalência do entendimento da Justiça Federal de Santa Catarina, que concedeu a pensão em um caso semelhante.

Nas palavras do relator da decisão Juiz Federal Marcelo Malucelli:

Quando se verificam presentes alguns pressupostos tais como a afetividade, a estabilidade e a ostentabilidade, é possível presumir a boa-fé da requerente, de maneira que em tais casos não há obstáculo ao reconhecimento de entidade familiar, no modelo estruturado sob a forma de concubinato. (TRF 4, 2015).

A justiça acatou que o concubinato impuro não retira o direito à pensão, mesmo o Código Civil vigente sendo claro no sentido de que não existe união estável com pessoas casadas, uma vez que os impedimentos à união estável são os mesmos aplicados ao matrimônio e, dentre as vedações do art. 1.521 do Código Civil, está o inciso VI, o qual impede pessoas casadas de contraírem união estável. Isto é reiterado no art. $1.723, \S 3^{\circ}$ do mesmo, no qual fica evidente que a pessoa casada, não separada de fato ou judicialmente, é impedida de contrair união estável. A lei não trouxe nenhum direito à relação oriunda de concubinato, mas não é isso que a jurisprudência entende e os juízes usam o pseudo princípio da afetividade para fundamentar suas decisões. Esta decisão é tão delicada que confronta a moral de muitas pessoas, e isto não é o certo quando se trata de hermenêutica jurídica, pois há uma resposta correta, especialmente porque a lei previu que o concubinato não gera obrigação patrimonial porque não tem como ser transformado em união estável. Neste caso, não havia nem mesmo o que se falar na "omissão da lei" citada no art. $4^{\circ}$ da Lei de Introdução às Normas do Direito Brasileiro.

Decisões como estas causam insegurança jurídica e a perda da confiança no Poder Judiciário. Apesar do positivismo ser criticado, não se pode negar os benefícios que ele traz, os quais são mencionados por Maia (2009, p. 123), quais sejam, "a inteligência da estrutura das normas jurídicas, a preocupação com a clareza, certeza e objetividade no estudo do direito e a preocupação com a segurança jurídica." Nesta situação, o juiz está se substituindo ao legislador, fazendo juízos morais e éticos e, como afirma $\operatorname{Streck}(2015$ b, p. 95), "um juiz não pode impor aos jurisdicionados os seus próprios valores, não pode construir sua decisão com base em argumentos de política. Isso não é ser democrático. O campo de atuação do juiz deve ser o normativo.”

\section{c) União estável poliafetiva}

Em São Paulo, na cidade de Tupã, um homem e duas mulheres conseguiram registrar a união estável, no ano de 2012. No Rio de Janeiro, no $15^{\circ}$ Ofício de Notas, em outubro de 2015, foi oficializada a união estável entre 3 mulheres, cuja tabeliã Fernanda Leitão usou o pseudo princípio da afetividade para justificar a aceitação do registro:

Fernanda Leitão explicou que o registro da união poliafetiva, por meio da lavratura da escritura pública, está fundamentada na aplicação do princípio da afetividade, que representa o novo pilar do Direito de Família, assim como nos princípios da dignidade da pessoa humana, da personalidade, da autonomia da vontade e da não discriminação. (SOUZA, 2016) 
A norma constitucional e a infraconstitucional não reconhecem esse tipo de família, a união estável, constitucionalmente prevista, é a entre homem e mulher, conforme se pode verificar da leitura do art. 1.723 do Código Civil.

Acerca destes novos arranjos familiares, o máximo que existe é o Projeto de Emenda Constitucional apresentado em 21 de outubro de 2015, de Bacelar (PTN-BA), que visa dar nova redação ao $\S 3^{\circ}$ do artigo 226, da Constituição Federal, reconhecendo como entidade familiar o núcleo social formado por duas ou mais pessoas unidas por laços sanguíneos ou afetivos, originados pelo casamento, união estável ou afinidade (CÂMARA, 2015).

O reconhecimento de união poliafetiva é fruto da interpretação extensiva da Resolução no 40 do Conselho Nacional de Justiça, de 14 de agosto de 2007, a qual em seu artigo art. $4^{\circ}$, dispõe que qualquer pessoa que esteja sob as condições mínimas exigíveis para firmar um contrato de união e que necessariamente não possua nenhum laço matrimonial anterior poderá se unir a outro e constituir união a partir de um contrato registrado em cartório. Contudo, esta é a leitura de um único artigo da Resolução, pois o art. $1^{\circ}$ da mesma estabelece que será considerado como entidade familiar "a convivência pública, contínua e duradoura entre o homem e a mulher, estabelecida com o objetivo de constituição de família." O legislador colocou os artigos definidos singulares "o" e "a", rechaçando qualquer interpretação que reconheça como entidade familiar a união entre "os homens e a mulher", "as mulheres e o homem", "os homens e as mulheres".

Para Alexandre, as relações poliafetivas se justificam com base no fato de que "demais entidades e arranjos não previstos constitucionalmente, que se formam em meio à sociedade, unidos pela afetividade que permeia as variadas relações familiares, passaram a ser reconhecidos."

A maior prova de que o princípio da afetividade, enquanto não positivado, não pode afastar o que a lei reconhece como família é que, em maio de 2016, o CNJ pediu a suspensão do registro de uniões poliafetivas por questões de prudência, até que se discuta com profundidade este tema que, segundo a ministra Nancy Andrighi, "extrapola os interesses das pessoas envolvidas na relação afetiva." O pedido é resultado de uma representação judicial da Associação de Direito de Família e das Sucessões (ADFAS), que alega que este tipo de arranjo familiar é inconstitucional (MANSUR, 2016). E é, conforme a atual redação do art. 226, $\S 3^{\circ}$,que estabelece que "para efeito da proteção do Estado, é reconhecida a união estável entre o homem e a mulher como entidade familiar."

Com este pedido do CNJ à Corregedoria Nacional de Justiça, espera-se que o pseudo princípio da afetividade não seja utilizado para embasar um tipo de arranjo familiar inconstitucional, pois mais grave do que o decisionismo judicial é o decisionismo administrativo de um Cartório.

\section{CONCLUSÃO}

Este artigo não teve como objetivo criticar ou elogiar o princípio da afetividade, mas, sim, a forma como vem sendo empregado, que, conforme nos julgados apresentados, as vezes, contra a Constituição Federal. Não existe no ordenamento constitucional brasileiro a possibilidade de união estável entre homens e mulheres, mas, sim, entre o homem e a mulher; não existe rol de direitos para concubinos e nem possibilidade jurídica para união estável poliafetiva.Entretanto, ainda assim, o decisionismo judicial faz com que, pretensões deste gênero sejam alcançadas pela via do Poder Judiciário e, por isso, critica-se o fato de que os juízes estão permitindo tais inovações mesmo sabendo que são vedadas por lei, com fundamento no princípio da afetividade, oqual ainda não ostenta normatividade alguma.

A dignidade da pessoa humana foi inserida no rol normativo da Constituição, irradiando efeito para todos os ramos do direito, porém, seu conteúdo não é exatamente jurídico, o que tem 
levado ao princípio a servir para justificar toda a discricionariedade judicial que chega ao ponto de criar pseudo-princípios para solucionar casos de acordo com a moral de um juiz insatisfeito com a solução que o texto legal fornece. Falta reflexão crítica sobre a dignidade da pessoa humana, que é usada indiscriminadamente e o pseudo princípio da afetividade é um dos resultados desta postura judicialativista.

Quando um juiz aplica um não direito, abre-se a possibilidade do Poder Legislativo se sentir menos responsável em sua tarefa de criar o Direito, pois pode se acomodar na postura ativista do Poder Judiciário, e quem perde com isso é sociedade que perderá no quesito democracia e segurança jurídica, afinal, os congressistas democraticamente eleitos poderão se sentir livres em sua inércia e o direito passará a ser não apenas o que o texto normativo dispõe, mas qualquer coisa passível de ser embasada em termos de afetividade.

A discricionariedade do juiz é antidemocrática, pois a utilização de princípios deste gênero, sempre oriundos da dignidade humana, violam a letra da lei gerando insegurança jurídica e é uma falta de respeito à deontologia jurídica. Decidir não deve ser uma escolha moral. Isso não significa uma postura positivista, uma vez que a aplicação de princípios, a utilização da ponderação é correta (o objeto deste trabalho não é a ponderação, mas até mesmo o resultado da ponderação é aplicado por subsunção), entretanto, não é correto substituir o Direito pela moral pessoal. Não se nega a importância da afetividade, entretanto, para que ela seja aplicada ao caso concreto, no mínimo, deverá ser elevada ao patamar normativo.

\section{REFERÊNCIAS}

BARRETO, Vicente de Paulo. O Fetiche dos Direitos Humanos e outros temas. 2. ed. Porto Alegre: Livraria do Advogado, 2013.

BARROSO, Luis Roberto. Neoconstitucionalismo e constitucionalização do Direito. Disponível em: <http://www.georgemlima.xpg.com.br/barroso.pdf>. Acesso em 23 nov.2016.

BOBBIO, Norberto. O positivismo jurídico: lições de filosofia do direito. São Paulo: Ícone, 1995.

BOTTINI FILHO, Luciano. Certidão de nascimento passa a admitir dois pais e uma mãe. 2013. Disponível em: <http://exame.abril.com.br/brasil/certidao-de-nascimento-passa-a-admitir-doispais-e-uma-mae/>. Acesso em $01^{\circ}$ dez. 2016.

BUSTAMANTE, Thomas da Rosa de. Teoria do precedente judicial: a justificação e a aplicação de regras jurisprudenciais. São Paulo: 2012.

DIAS, Maria Berenice Dias. Manual de Direito das Famílias. 3. ed. São Paulo: Revista dos Tribunais, 2006.

DWORKIN, Ronald. A Justiça de Toga. São Paulo: Martins Fontes, 2010.

G1. Criança é registrada com dois pais após decisão da Justiça em SP. Disponível em: $<$ http:// g1.globo.com/sao-paulo/noticia/2015/10/crianca-e-registrada-com-dois-pais-apos-decisao-dajustica-em-sp.html.> Acesso em $01^{\circ}$ dez. 2016.

KELSEN, Hans. Teoria pura do Direito. 7. ed. Coimbra: Almedina, 2008. 
MAIA, Antônio Cavalcanti. Nos vinte anos da carta cidadã: do pós-positivismo ao neoconstitucionalismo. In: SOUZA NETO, Cláudio Pereira de; SARMENTO, Daniel; BINENBOJM (coordenadores). Vinte anos daConstituição Federal de 1988. Rio de Janeiro: Lumen Juris, 2009.

MANSUR, Pedro. CNJ pede suspensão do registro de uniões poliafetivas. Disponível em: $<$ http://oglobo.globo.com/sociedade/cnj-pede-suspensao-do-registro-de-unioes-poliafetivas-19 359327>. Acesso em 06 dez. 2016.

MORAIS, Fausto Santos de; SANTOS, José Paulo Schineider dos. A teoria da constituição dirigente como imaginário para a hermenêutica constitucional brasileira. Revista de Direito Brasileira. Ano 5. Vol. 10, 2015.

RADBRUCH, Gustav. Filosofia do Direito. Coimbra: Armênio Amado Editor, 1974.

REBOSSIO, Alejandro. Argentina registra o seu primeiro bebê com três pais.24 abr. 2015. Disponível em: <http://brasil.elpais.com/brasil/2015/04/24/internacional/1429827035368004. html>. Acesso em $01^{\circ}$ dez. 2016.

SILVA, Renan Apolônio de Sá. Princípio da Afetividade. Disponível em: <http://www.ju risway.org.br/v2/dhall.asp?pagina=20\&idarea=20\&id_dh=17829>. Acesso em 04 dez. 2016.

SOUZA, Giselle. Tabeliã diz que registro de união poliafetiva é evolução do Direito de Família. Disponível em: <http://www.conjur.com.br/2016-abr-14/tabelia-registro-uniao-poliafetiva evolucao-direito>. Acesso em 06 dez. 2016.

STRECK, Lenio Luiz. Compreender direito: nas brechas da lei. Vol. 3. São Paulo: Revista dos Tribunais, $2015 \mathrm{~b}$.

O pamprincipiologismo e a flambagem do Direito. 2013 Disponível em: <http://www.conjur.com.br/2013-out-10/senso-incomum-pamprincipiologismo-flambagemdireito $>$. Acesso em 02 dez. 2016.

STRECK, Lenio Luiz. Por analogia, advogados devem invocar em seu favor o princípio da amorosidade! 2014. Disponível em: <http://www.conjur.com.br/2014-set-18/senso-incomumanalogia-advogados-invocar-principio-amorosidade> . Acesso em 30 nov. 2016.

- Lições de crítica hermenêutica do direito. 2. ed. Porto Alegre: Livraria do Advogado. 2016.

. O que é isto? Decido conforme minha consciência. 5. ed. Porto Alegre: Revista dos Tribunais, 2015.

. Verdade e consenso. Rio de Janeiro: Lumen Juris, 2008.

TARTUCE, Flávio. O Princípio da Afetividade no Direito de Família. Disponível em: <https://flaviotartuce.jusbrasil.com.br/artigos/121822540/o-principio-da-afetividade-no-direitode-familia >. Acesso em $01^{\circ}$ dez. 2016. 
TAVARES, Rodrigo de Souza. 2007. Neoconstitucionalismo e positivismo inclusivo. Disponível em: <http://jus.com.br/revista/texto/9897/neoconstitucionalismo-e-positivismo-inclusivo>. Acesso em 05 dez. 2015.

TRIBUNAL DE JUSTIÇA DE GOIAS. Assegurado a criança o direito de ter duas mães e um pai no registro civil. Disponível em: <http://www.tjgo.jus.br/index.php/ho me/imprensa/noticias/119-tribunal/11372-multiparentalidade-justica-assegura-a-crianca-odireito-de-ter-duas-maes-e-um-pai-no-registro-civil>. Acesso em 06 dez. 2016.

TRF 4. Juizados: Mulher que mantinha caso extraconjugal com segurado falecido dividirá pensão com esposa. Disponível em: <http://www2.trf4.jus.br/trf4/contro lador.php?acao=noticia_visualizar\&id_noticia=11091>. Acesso em 04 dez. 2016.

WALDRON, Jeremy. A essência da oposição ao Judicial Review. In: BIGONHA, Antônio Carlos Alpino; MOREIRA, Luiz. Legitimidade da jurisdição constitucional. Rio de Janeiro: Lumen Juris, 2010. 